\title{
PERLINDUNGAN HUKUM BAGI AWAK KABIN DALAM PERJANJIAN WAKTU TERTENTU (PKWT) PT GARUDA INDONESIA
}

\author{
Anastasia, Ida Ayu Putu Widiati, A.A Sagung Laksmi Dewi \\ Fakultas Hukum, Universitas Warmadewa, Denpasar-Bali, Indonesia \\ anastasiavalentine14@gmail.com, widiati_dayu@yahoo.co.id, laksmidewii29@gmail.com
}

\begin{abstract}
Abstrak
Keberadaan awak kabin sangat dibutuhkan dalam suatu penerbangan untuk melayani penumpang pesawat, tidak terkecuali dengan Garuda Indonesia sebagai salah satu penerbangan milik BUMN yang berusaha memberikan keselamatan penerbangan dalam bidang transportasi udara. Penelitian ini bertujuan untuk mengetahui pelaksanaan Perjanjian Kerja Waktu Tertentu (PKWT) pada awak kabin Garuda Indonesia homebase Denpasar dan mengetahui perlindungan hukum bagi pramugari dalam Perjanjian Kerja Waktu Tertentu (PKWT) pada awak kabin Garuda Indonesia homebase Denpasar. Jenis penelitian yang digunakan adalah penelitian empiris. Penelitian empiris dilakukan terhadap keadaan nyata pada masyarakat atau lingkungan sekitar dengan tujuan untuk menemukan fakta-fakta atau permasalahan hukum yang ada. Hasil penelitian menunjukan bahwa pelaksanaan Perjanjian Kerja Waktu Tertentu (PKWT) pada awak kabin PT Garuda Indonesia homebase Denpasar erat hubungannya dengan ketenagakerjaan antara pekerja dengan perusahaan. Perjanjian Kerja Waktu Tertentu (PKWT) di PT Garuda Indonesia diatur dalam Peraturan Perusahaan. Secara umum tentang perlindungan terhadap pekerja telah diatur dalam Undang-Undang No. 13 Tahun 2003 tentang Ketenagakerjaan. Sikap keterbukaan upah terhadap awak kabin pasti akan berdampak positif pagi kesejahtraan karyawan.
\end{abstract}

Kata Kunci: Perlindungan Hukum, Perjanjian Kerja, Awak Kabin, Garuda Indonesia

\begin{abstract}
The existence of cabin crew is very much needed in a flight to serve airplane passengers, including Garuda Indonesia as one of the state-owned airlines that tries to provide flight safety in the field of air transportation. This study aims to determine the implementation of the Specific Time Work Agreement (PKWT) on the cabin crew of Garuda Indonesia homebase Denpasar and to find out the legal protection for flight attendants in the Fixed Time Work Agreement (PKWT) on the cabin crew of Garuda Indonesia homebase Denpasar. This type of research is empirical research. Empirical research is carried out on the real situation in the community or the surrounding environment with the aim of finding facts or existing legal problems. The results showed that the implementation of the Fixed Time Work Agreement (PKWT) on the cabin crew of PT Garuda Indonesia homebase Denpasar is closely related to employment between workers and companies. Fixed Term Work Agreement (PKWT) at PT Garuda Indonesia is regulated in Company Regulations. In general, the protection of workers has been regulated in Law No. 13 of 2003 concerning Manpower. The attitude of open wages to cabin crew will definitely have a positive impact on the welfare of employees in the morning.
\end{abstract}

Keywords: Legal Protection, Work Agreement, Cabin Crew, Garuda Indonesia

\section{PENDAHULUAN}

PT Garuda Indonesia menggunakan sistem vendor yang bekerja sama dengan perusahaan lain dan perusahaan tersebut disebut anak perusahaan PT Garuda Indonesia. Untuk pekerja pada anak perusahaan PT Garuda Indonesia yang tidak tetap mengandalkan tenaga kerja outsourcing. Sementara, untuk tenaga kerja kontrak di dalam PT Garuda Indonesia disebut Perjanjian Kerja Waktu Tertentu (PKWT). Penyebab adanya 2 sistem dalam pekerjaan yaitu terdapat suatu faktor perekonomian yang berkembang dengan pesat yang menuntut perusahaan agar dapat memberikan suatu pelayanan yang lebih baik, akan tetapi disamping itu perusahaan juga dituntut untuk dapat membrikan harga yang semurah-murahnya dengan mendapat keuntungan yang lebih besar. Maka dari itu kebanyakan perusahaan yang terpaksa harus mengubah sistem manajemennya agar sistem tersebut bisa berjalan lebih efisien dan efektif.

Dengan perubahaan sistem manajemen tersebut, dalam produksi perusahaan menjadi mengeluarkan biaya yang lebih kecil yaitu dengan merubah sistem pekerja menjadi pekerja kontrak yang pekerja tersebut diborongkan oleh pihak lain yang menyediakan jasa tersebut, kontrak yang waktunya continue atau dengan sistem Perjanjian Kerja Waktu Tertentu yang selanjutnya disebut 
sebagai PKWT. Akan tetapi, dengan mempergunakan sistem tersebut perusahaan harus bisa memenuhi kewajibannya yaitu memberikan hak yang sebagaimana mestinya yang telah diatur didalam undangundang ketenagakerjaan disebutkan mengenai perlindungan hukum terhadap pekerja, yaitu bahwa dalam undang-undang tersebut dikatakan bahwa setiap orang berhak mendapat pekerjaan dan menghidupi diri dengan layak untuk kehidupannya. Undang-undang tersebut berkaitan dengan perlindungan yang diberikan untuk setiap orang agar mendapat perkekonomian yang layak dan tidak mendapat tindakan diskriminasi dari pihak-pihak tertentu di suatu perusahaan.

Dalam undang-undang ketenagakerjaan juga disebutkan mengenai setiap orang mempunyai hak untuk dapat bekerja dengan penghasilan yang layak untuk kehidupannya serta tidak dipandang sebelah mata serta diperlakukan dengan seadil-adilnya tanpa mengurangi haknya. Artinya disini antara salary dan prestasinya yang diberikan perusahaan balance atau seimbang serta layak untuk pekerja dan perusahaan juga tidak boleh mendiskriminasi ataupun bertindak yang seadil-adilnya terhadap setiap pekerja (Asshiddiqie, 2013). Karena di Indonesia ini banyak perusahaan BUMN atau perusahaan swasta yang mempekerjakan tenaga kerja kontrak atau PKWT tetapi tidak memenuhi hak-hak yang telah diatur di dalam UUK, kebanyakan perusahaan tersebut hanya memberikan gaji atau upah kerja dan tidak tahu menahu atau tidak memperhatikan mengenai hak lainnya yang telah diatur didalam UUK.

Dengan diberlakukannya Undang-Undang Ketenagakerjaan dengan maksud untuk membentuk suatu tenaga kerja yang berkualitas sehingga para pekerja bisa ikut serta mengembangkan perusahaan agar perlindungan terhadap tenaga kerja termasuk keluarganya semakin meningkat untuk mencapai harkat dan martabatnya sebagai pekerja. Agar hak sebagai seorang pekerja terjamin tanpa adanya perbedaan antara pekerja yang satu dengan yang lainnya dan tidak ada diskriminasi terhadap para pekerja (Tunggal, 2009). Yang sering terjadi yaitu adanya perjanjian mengenai perburuhan yang artinya perjanjian tersebut dibuat antara pekerja dengan majikannya yang dengan perjanjian tersebut pekerja mengikatkan dirinya kepada majikan bahwa ia akan menjalankan segala perintah dari majikannya, majikan akan memberikan kehidupan yang layak untuk pekerja serta dengan keluarganya sebagai pekerja dan majikan yang baik sesuai dengan perjanjian yang telah mereka sepakati (Wahyudi dkk, 2016).

Kebanyakan suatu perusahaan membutuhkan pekerja tetap yang bisa menjalankan pekerjaan pokok dalam kegiatan produksi perusahaannya (Fithriatus, 2016). Pada PT Garuda Indonesia sendiri dilihat dari track record mengenai pemberian hak kepada tenaga kerja kontrak dan PKWT sendiri pernah bermasalah, permasalahannya yaitu pada tahun 2010 dan tahun sebelum sebelumnya, sebelum pihak kementrian BUMN dan pihak jajaran pimpinan PT Garuda Indonesia memperbaiki dan menertibkan sistem yaitu mengenai waktu dipekerjakannya tenaga kontrak dan PKWT tersebut telah melebihi batas yang ditetapkan oleh UUK, dan seketika menimbulkan protes dan demo para karyawan atau pekerja kontrak dan PKWT menuntut haknya untuk dijadikan sebagai tenaga kerja tetap pada PT Garuda Indonesia.

Pada kenyataanya sering terjadi perbuatan yang menyimpang dari ketentuan perundang- undangan yang berlaku mengenai perjanjian kerja. Penyimpangan terhadap ketentuan perundang-undangan yang sering terjadi yaitu pelaksanaan perjanjian kerja yang tidak memenuhi kebutuhan pokok terhadap lapangan pekerjaan dan suatu perusahaan yang tidak dapat merekrut seorang pekerja yang tidak dibutuhkan dalam kegiatan pokok perusahaannya, karena Kebanyakan perusahaan membutuhkan pekerja tetap yang bisa menjalankan pekerjaan pokok dalam kegiatan produksi perusahaannya.

Sejumlah penelitian yang serupa dan relevan pernah dikaji diantaranya, yaitu perlindungan hukum bagi pekerja dalam perjanjian kerja waktu tertentu (PKWT) di CV. Shofa Marwah (S. K. Sari, 2011), di samping itu penelitian serupa lainnya tentang perlindungan Hukum terhadap Pekerja dalam Perjanjian Kerja Waktu Tertentu Menurut Undang-Undang no 13 Tahun 2003 (Sari, Budiartha, \& Arini, 2020), selanjutnya penelitian yang membahas tentang perlindungan hukum bagi pekerja dalam perjanjian kerja waktu tertentu di PT. Panji Dananjaya (Setiawan, 2011).

Dari uraian di atas, maka penelitian baru ini bertujuan untuk menganalisis pelaksanaan Perjanjian Kerja Waktu Tertentu (PKWT) pada awak kabin PT Garuda Indonesia dan mengetahui bentuk perlindungan hukum bagi awak kabin dalam Perjanjian Kerja Waktu Tertentu (PKWT) di PT Garuda Indonesia. 


\section{METODE PENELITIAN}

Jenis penelitian yang digunakan adalah penelitian hukum empiris. Penelitian hukum empiris merupakan penelitian yang berkaitan dengan hukum dan perilaku manusia. Dalam memperoleh data yang akurat, peneliti berperan sebagai "key instrument" yang terjun langsung ke lapangan. Pendekatan masalah yang digunakan dalam penelitian ini adalah pendekatan yuridis sosiologis. Pendekatan yuridis sosiologis adalah suatu penelitian yang dilakukan terhadap keadaan nyata yang terjadi di masyarakat atau di lapangan dengan tujuan untuk menemukan fakta-fakta atau permasalahan yang ada, dan menuju pada identifikasi, dan akhirnya menuju pada penyelesaian masalah.

Sumber data dalam penelitian ini terbagi dua berbentuk yaitu data primer dan data sekunder, 1) Data primer, Data primer adalah data yang terdiri atas hasil wawancara langsung dari narasumber dan responden. Wawancara ini dilakukan dengan informan di lapangan serta suatu pedoman yang berkaitan dengan Perjanjian Kerja Waktu Tertentu 2) Data Sekunder, Data sekunder adalah sumber data penelitian yang diperoleh melalui media perantara atau secara tidak langsung yang berupa buku, catatan, bukti yang telah ada, atau arsip baik yang dipublikasikan maupun yang tidak dipublikasikan secara umum, yang terdiri dari Bahan Hukum Primer dan Bahan Hukum Sekunder termasuk juga literatur, kamus, beserta tulisan ilmiah lainnya yang berkaitan dengan pokok permasalahan yang dikaji. Dalam penelitian ini juga dilakukan observasi dan wawancara langsung dengan mendatangi PT Garuda Indonesia Homebase Denpasar dan mengadakan tanya jawab dengan pihak-pihak yang terkait langsung dengan masalah yang dibahas dan mengambil data dengan mengamati dokumen-dokumen dan arsiparsip yang diberikan oleh pihak yang terkait, dalam hal ini pihak PT Garuda Indonesia.

\section{HASIL DAN PEMBAHASAN}

Pelaksanaan Perjanjian Kerja Waktu Tertentu (PKWT) pada awak kabin Garuda Indonesia homebase Denpasar erat hubungannya dengan ketenagakerjaan antara pekerja dengan perusahaan. Perjanjian Kerja Waktu Tertentu (PKWT) di Garuda Indonesia diatur dalam Peraturan Perusahaan. Peraturan Perusahaan adalah suatu pedoman penentuan syarat- syarat kerja dan kondisi kerja sebagai salah satu sarana untuk mewujudkan hubungan industrial. Bahan hukum yang diteliti adalah Perjanjian Kerja Waktu Tertentu Awak Kabin Reguler, No: Garuda/JKTID/90752/PKWT/Reg/11 dalam PKWT ini terdapat 12 pasal yang mengikat antara pekerja dan perusahaan yang akan dianalisis berdasarkan Undang-Undang No.13 Tahun 2003 tentang ketenagakerjaan. Sayangnya, menurut (Amalia, Ginting, Agusmidah, \& Yefrizawati, 2017; Shalihah, 2016) bahwa penerapan perjanjian kerja waktu tertentu (PKWT) dalam hubungan kerja menurut Undang-Undang Nomor 13 Tahun 2003 tentang Ketenagakerjaan belum berjalan sesuai dengan ketentuan yang berlaku. Pada penelitian lain, diungkap bahwa ketidaksesuaian yang dimaksud adalah karena dalam penerapan perjanjian tersebut masih melanggar ketentuan yang telah diatur oleh Undang-Undang yaitu mengenai PKWT yang seharusnya wajib dibuat dalam bentuk tertulis atau dicatatkan melainkan dibuat secara lisan (Kusuma \& Wairocana, 2014). Selain itu juga dikarenakan masih banyaknya penyimpangan aturan tentang PKWT yang tidak sesuai dengan Undang-Undang Nomor 13 Tahun 2003 tentang Ketenagakerjaan (Wijayanti, 2018).

Hubungan kerja terjadi karena adanya kebutuhan dari kedua belah pihak yaitu pekerja dan perusahaan untuk mengakomodir tujuan perusahaan. Dimana pekerja sebagai pencari kerja memerlukan pekerjaan dan perusahaan sebagai pembuka lapangan kerja sebagai pihak yang mempekerjakan. Hubungan kerja merupakan salah satu bentuk hubungan hukum, akan tetapi di dalam hubungan kerja terdapat karakteristik tersendiri yang membedakan dengan hubungan-hubungan hukum yang lainnya.

Perjanjian Kerja Waktu Tertentu (PKWT) pada perjanjian kerja yang menjadi bahan hukum penelitian yaitu Perjanjian Kerja Waktu Tertentu Awak Kabin Reguler, No: Garuda/JKTID/90752/PKWT/REG/11 dibuat secara tertulis oleh pihak perusahaan, hal ini sesuai dengan pasal 57 ayat (1) yang menyatakan perjanjian kerja untuk waktu tertentu dibuat secara tertulis serta harus menggunakan bahasa Indonesia dan huruf latin, sedangkan PKWT tertuang dalam pasal 56 ayat (1) yang menyatakan perjanjian kerja dibuat untuk waktu tertentu atau untuk waktu tidak tertentu. Ayat (2) menyatakan perjanjian kerja waktu tertentu sebagaimana dimaksud dalam ayat (1) didasarkan atas jangka waktu dan selesainya suatu pekerjaan tertentu. Dalam (Gultom, 2018) disebutkan bahwa proses pengadaan pilot banyak yang tidak sesuai dengan aturan yang terdapat di PKP. Misalnya, penerimaan pilot dengan status PKWT yang tidak sesuai dengan PKP Pasal 5 dan UU No.13 Tahun 2003 Pasal 59 tentang Ketenagakerjaan dan Kepmenakertrans No.KEP.100/ MEN/VI/2004 mengenai ketentuan PKWT. 
Pada perjanjian kerja yang dilakukan oleh Garuda Indonesia sebagai pihak Pertama dan awak kabin sebagai pihak Kedua. Pada pasal 1 ayat (1) menyatakan "Pihak Kedua bersedia bekerja pada Pihak Pertama sebagaimana Pihak Pertama bersedia menerima Pihak Kedua bekerja sebagai awak kabin berstatus hubungan kerja untuk waktu tertentu dengan jangka waktu paling lama 2 (dua) tahun". Dari penjelasan pasal diatas maka dapat dilihat perjanjian kerja dapat saja sebelum 2 (dua) tahun berakhir karena seperti yang tercantum paling lama 2 (dua) tahun perjanjian kerja ini berlaku. Hal ini sejalan dengan pasal 56 ayat (1) dan (2).

Dalam perjanjian kerja yang disepakati oleh Garuda Indonesia dan awak kabin terdapat 2 (dua) pasal yang menyatakan mengenai berakhirnya hubungan kerja yaitu pasal 7 ayat 2 (dua) yang menyatakan "Seandainya dalam masa Perjanjian Kerja Waktu Tertentu Pihak Kedua tidak memenuhi persyaratan sebagai awak kabin sesuai dengan ketentuan Pihak Pertama, maka hubungan kerja Pihak Pertama dengan Pihak Kedua berakhir serta perjanjian ini putus dengan sendirinya". Dalam pasal di atas dinyatakan bahwa awak kabin harus memiliki kompetensi seperti yang disyaratkan oleh Garuda Indonesia selaku pemberi kerja. Persyaratan disini seperti kompetensi awak kabin mengenai standar servis yang dimiliki oleh perusahaan, penampilan, dan softskill lainnya yang mendukung pekerjaan sebagai awak kabin. Hal tersebut menjadi sangat penting untuk menjaga citra maskapai di mata penumpang sehingga nantinya tidak terjadi penurunan penumpang yang diakibatkan oleh pelayanan yang kurang maksimal oleh awak kabin sehingga dapat merugikan perusahaan. Sedangkan pasal yang menyatakan berakhirnya perjanjian kerja terdapat juga di pasal 8 yang menyatakan "Pihak Pertama akan melakukan pemutusan hubungan kerja kepada Pihak Kedua apabila Pihak Kedua melakukan pelanggaran disiplin tingkat II atau tingkat III berdasarkan ketentuan disiplin Pihak Pertama". Pada pasal ini tidak dituangkan secara jelas apa yang dimaksud dengan pelanggaran disiplin, tetapi diatur didalam Peraturan Perusahaan. Peraturan Perusahaan bisa saja berubah setiap tahunnya atau setiap periode, jadi dengan adanya pasal ini tidak jelas Peraturan Perusahaan yang mana yang nantinya akan menjadi rujukan apabila ada pelanggaran yang dilakukan awak kabin. Sebaiknya dicantumkan penggunaan Peraturan Perusahaan yang menjadi rujukan karena perjanjian kerja yang dibuat berlaku selama 2 (dua) tahun. Untuk menghindari perbedaan penafsiran sebaiknya dicantumkan dengan jelas rujukan tahun berapa yang digunakan karena apabila terjadi perbedaan penafsiran tahun maka yang digunakan adalah tahun Peraturan Perusahaan yang ada dalam perjanjian kerja tersebut. Perjanjian kerja waktu terbatas pada dasarnya tidak dapat diterapkan untuk semua jenis pekerjaan, ada suatu pekerjaan yang memang tidak bisa menggunakan perjanjian tersebut. Pekerjaan yang dapat diterapkan dengan perjanjian tersebut yaitu suatu pekerjaan yang sifatnya sementara, pekerjaan yang bisa diselesaikan dengan waktu yang singkat, pekerjaan produksi yang masih dalam tahap percobaan ataupun pekerjaanpekerjaan sambilan yang sifatnya freelance atau sementara waktu. Karena Kebanyakan suatu perusahaan membutuhkan pekerja tetap yang bisa menjalankan pekerjaan pokok dalam kegiatan produksi perusahaannya. Hal ini sesuai dengan perjanjian kerja yang dilakukan oleh Garuda Indonesia dengan awak kabin yaitu pada pasal 1 ayat (1) yang menyatakan "Pihak Kedua bersedia bekerja pada Pihak Pertama sebagai mana Pihak Pertama bersedia menerima Pihak Kedua bekerja sebagai pegawai awak kabin berstatus hubungan kerja untuk waktu tertentu dengan jangka waktu paling lama 2 (dua) tahun". Perjanjian kerja yang dilakukan dapat diperpanjang kembali tetapi dengan adanya perjanjian kerja yang baru maka perjanjian kerja yang sebelumnya akan gugur dengan sendirinya demi hukum.

Dalam undang-undang ketenagakerjaan disebutkan bahwa suatu perusahaan yang menggunakan jasa awak kabin harus mengikuti ketentuan undang-undang ketenagakerjaan yang berlaku, apabila suatu perusahaan diketahui tidak memenuhi aturan tersebut dengan perjanjian kerja waktu tertentu maka perusahaan yang bersangkutan tersebut akan dikenakan sanksi seusai dengan yang ditentukan oleh aturan tersebut. Dalam undang- undang ketenagakerjaan menyatakan "Perjanjian kerja untuk waktu tertentu yang tidak memenuhi ketentuan sebagaimana di maksud pada ayat (1), ayat (2), ayat (4), ayat (5) dan ayat (6), maka demi hukum menjadi perjanjian kerja waktu tidak tertentu".

Ketentuan yang disebutkan dalam undang-undang ketenagakerjaan untuk pekerja awak kabin menggunakan sistem perjanjian kerja waktu tertentu, artinya dalam pekerjaan sebagai awak kabin sistem perjanjian tersebut sangat tepat untuk diterapkan karena posisi sebagai awak kabin tidak boleh mengambil pekerjaan lain yang memang tidak bagiannya, artinya disini sebagai awak kabin perlindungannya sangat terjamin dengan adanya sistem perjanjian tersebut. Dengan demikian maka berdasarkan atas ketentuan yang terdapat dalam undang-undang ketenagakerjaan bahwa seorang yang bekerja di bagian awak kabin akan berubah menjadi perjanjian kerja waktu tidak tertentu yang bukan 
lagi waktu tertentu. Maka dapat dikatakan bahwa ada hal menyimpang yang terjadi terhadap ketentuan dari undang-undang ketenagakerjaan karena tidak jelasnya pekerjaan dari seorang awak kabin dan tidak sesuai dengan posisinya sebagai awak kabin. Dalam uraian diatas terlihat bahwa penelitian ini berkaitan kurangnya pengawasan terhadap ketentuan dari undang-undang ketenagakerjaan oleh pemerintah sehingga masih adanya perbuatan menyimpang. Pentingnya upah yang diterima oleh seorang awak kabin sehingga dalam undang-undang ketenagakerjaan disebutkan bahwa setiap pekerja/buruh mempunyai hak unduk mendapat upah penghidupan yang layak bagi kemanusiaan. Artinya jumlah upah yang diterima seorang awak kabin bisa digunakan untuk memenuhi kebutuhannya sendiri maupun untuk memenuhi kebutuhan keluarganya sesuai dengan kebutuhan pokok dari keluarga atau seorang awak kabin tersebut.

Perjanjian kerja waktu tertentu dan perjanjian kerja waktu tidak tertentu tidak bisa disamakan dengan upah sedemikian yang diterima oleh awak kabin, karena disini upah yang diberikan berdasarkan atas perjanjian waktu tertentu bukan perjanjian waktu tidak tertentu, disini terlihat bahwa adanya perbuatan menyimpang dari suatu perusahaan bahwa seorang awak kabin bekerja tidak sesuai dengan perjanjian dan upahnya tidak sesuai dengan pekerjaan yang dijalankannya. Bahwa awak kabin harus memiliki kompetensi seperti yang disyaratkan oleh Garuda Indonesia selaku pemberi kerja. Persyaratan disini seperti kompetensi awak kabin mengenai standar servis yang dimiliki oleh perusahaan, penampilan, dan softskill lainnya yang mendukung pekerjaan sebagai awak kabin. Hal tersebut menjadi sangat penting untuk menjaga citra maskapai di mata penumpang sehingga nantinya tidak terjadi penurunan penumpang yang diakibatkan oleh pelayanan yang kurang maksimal oleh awak kabin sehingga dapat merugikan perusahaan. Dengan melakukan pekerjaan berdasarkan atas waktu tidak tertentu yang sifatnya sementara, dan hanya melakukan pekerjaan pelengkap, maka suatu perusahaan mempunyai hak untuk mengatur sendiri sistem pengupahan terhadap pekerjanya.

Suatu pekerjaan yang dikerjakan merupakan suatu pekerjaan yang sifatnya hanya pelengkap, sehingga beban pekerjaan dengan pekerjaan pokok yang dilakukan oleh pekerja tetap berbeda. Maka pentingnya perlindungan yang diberikan kepada awak kabin mengingat perusahaan yang sudah melakukan perbuatan menyimpang dari ketentuan. Yang saat ini awak kabin hanya mendapatkan upahnya beberapa persen saja dimana upah tersebut tidak cukup untuk biaya penghidupannya melainkan hanya habis untuk digunakan sebagai biaya oprasionalnya saja. Perjanjian kerja waktu tertentu dan perjanjian kerja waktu tidak tertentu tidak bisa disamakan dengan upah sedemikian yang diterima oleh awak kabin, karena disini upah yang diberikan berdasarkan atas perjanjian waktu tertentu bukan perjanjian waktu tidak tertentu, disini terlihat bahwa adanya perbuatan menyimpang dari suatu perusahaan bahwa seorang awak kabin bekerja tidak sesuai dengan perjanjian dan upahnya tidak sesuai dengan pekerjaan yang dijalankannya. Sejalan dengan yang dikatakan oleh Maulinda, Dahlan, \& Rasyid (2016) bahwa seharusnya upah yang diberikan sesuai dengan yang telah mereka kerjakan. Terlihat bahwa tidak jelasnya mengenai ketentuan perjanjian kerja waktu tertentu sehingga adanya perbuatanperbuatan menyimpang yang masing sering terjadi, sehingga perlunya pengawasan lebih ketat lagi untuk memberikan perlindungan terhadap pekerja khususnya pekerja awak kabin.

\section{SIMPULAN DAN SARAN}

\section{Simpulan}

Dari penjelasan pendahuluan sampai dengan hasil penelitian dan pembahasan, maka dapat disimpulkan yaitu: 1) Pelaksanaan Perjanjian Kerja Waktu Tertentu (PKWT) pada awak kabin PT. Garuda Indonesia dengan perjanjian "Perjanjian Kerja Waktu Tertentu Awak Kabin Reguler, No: Garuda/JKTID/90752/PKWT/REG/11" sudah sesuai dengan Undang- Undang N0.13 Tahun 2003 tentang ketenagakerjaan. 2) Perlindungan hukum dalamPerjanjian Waktu Tertentu (PKWT) pada awak kabin PT Garuda Indonesia dengan perjanjian "Perjanjian Kerja Waktu Tertentu Awak Kabin Reguler, No: Garuda/JKTID/90752/PKWT/REG/11" sudah sesuai dengan Undang-Undang No.13 Tahun 2003 tentang ketenagakerjaan.

\section{Saran}

Dalam hal ini PT Garuda Indonesia seharusnya mencantumkan pasal pada Undang-Undang No.13 Tahun 2003 tentang Ketenagakerjaan khususnya untuk awak kabin yang belum tertuang di dalam perjanjian kerja seperti pada pasal 81 sehingga awak kabin tidak mengetahui hak yang bisa mereka dapatkan pada saat terjadinya kesepakatan kerja. Harapan kedepannya hal ini dapat dicantumkan pada 
perjanjian kerja bukan hanya ada di dalam Peraturan Perusahaan saja. Perlindungan terhadap upah sudah berjalan sesuai dengan Undang-Undang No.13 Tahun 2003 tentang Ketenagakerjaan dan Hal ini harus di pertahankan agar perjanjian kerja yang dibuat antara awak kabin dan Garuda Indonesia menguntungkan kedua belah pihak.

\section{DAFTAR PUSTAKA}

Amalia, A., Ginting, B., Agusmidah, \& Yefrizawati. (2017). Analisis Yuridis Perjanjian Kerja Waktu Tertentu Berdasarkan Undang- Undang Ketenagakerjaan dan Hukum Perjanjian. USU Law Journal, 5(1).

Asshiddiqie, J. (2013). Komentar Atas Undang-Undang Negara Republik Indonesia Tahun 1945.

Fithriatus, S. (2016). Implementasi Perjanjian Kerja Waktu Tertentu (PKWT) dalam Hubungan Kerja di Indonesia. Jurnal Selat, 4(1), 70-100.

Gultom, T. (2018). Serikat Pekerja dan Asosiasi Pilot Garuda Bersatu. APG Magazine, XLIII.

Kusuma, A. A., \& Wairocana, G. N. (2014). Pelaksanaan Perlindungan Hukum terhadap Karyawan Kontrak mengenai Perjanjian Kerja Waktu Tertentu Tidak Dicatatkan Berdasarkan Undang-Undang Nomor 13 Tahun 2003 pada CV. Wijaya Steel. Kertha Semaya: Journal Ilmu Hukum, 2(1), 1689-1699.

Maulinda, R., Dahlan, \& Rasyid, M. N. (2016). Perlindungan Hukum bagi Pekerja Kontrak Waktu Tertentu dalam Perjanjian Kerja pada PT. Indotruck Utama. Kanun Jurnal Ilmu Hukum, 18(3), 337-351.

Sari, N. P. N. E., Budiartha, I. N. P., \& Arini, D. G. D. (2020). Perlindungan Hukum terhadap Pekerja dalam Perjanjian Kerja Waktu Tertentu Menurut Undang-Undang no 13 Tahun 2003. Jurnal Analogi Hukum, 2(1), $124-128$

Sari, S. K. (2011). Perlindungan Hukum Bagi Pekerja Dalam Perjanjian Kerja Waktu Tertentu (PKWT) Di CV. Shofa Marwah (Universitas Sebelas Maret Surakarta).

Setiawan, M. A. (2011). Perlindungan Hukum Bagi Pekerja dalam Perjanjian Kerja Waktu Tertentu di PT. Panji Dananjaya (Universitas Sebelas Maret Surakarta).

Shalihah, F. (2016). Implementasi Perjanjian Kerja Waktu Tertentu (Pkwt) dalam Hubungan Kerja di Indonesia. Jurnal Selat, 4(1).

Tunggal, H. S. (2009). Himpunan Peraturan Ketenagakerjaan.

Wahyudi dkk. (2016). Hukum Ketenagakerjaan. Jakarta: Sinar Grafindo.

Wijayanti, R. (2018). Effectiveness of Legal Protection on Employees/Labours in a Fixed-Term Employment Contract in Golden Tulip Bay View Hotel \& Convention-Bali. Jurnal Hukum Prasada, 5(2), 90-99. 